\begin{tabular}{l|c|c}
\hline ISSN: 0001-5113 & ACTA ADRIAT., & SHORT COMMUNICATION \\
AADRAY & $59(2): 225-230,2018$ & \\
\hline
\end{tabular}

DOI:10.32582/aa.59.2.8.

\title{
New records of two carangid species from the south-east coast of Sicily (Ionian Sea) and considerations about their presence and abundance
}

\author{
Francesco TIRALONGO ${ }^{12}{ }^{*}$, Daniele TIBULLO ${ }^{1}$, Giuseppina MESSINA ${ }^{2}$ and \\ Bianca Maria LOMBARDO ${ }^{2}$
}

\begin{abstract}
${ }^{1}$ Ente Fauna Marina Mediterranea, 2, M. Rapisardi Street trav. VIII, 96012, Avola (SR), Italy
${ }^{2}$ Department of Biological, Geological and Environmental Sciences - University of Catania, 95124 Catania, Italy
\end{abstract}

"Corresponding author: fra.tiralongo@hotmail.it

New records of Pseudocaranx dentex (Bloch \& Schneider, 1801) and Seriola fasciata (Bloch, 1793) are reported from the Mediterranean Sea. During the period 2013-2017, we have collected several records of both species from the south-east coast of Sicily (Ionian Sea). On the basis of our and published data, we can consider $S$. fasciata as a relatively common species in the area, commonly caught with purse seine around FADs in summer and autumn; while, P. dentex remains basically a rare species, occasionally caught with trammel nets or gillnets. This work represents the first well-documented records of both carangid species in the south-east coast of Sicily.

Key words: Seriola fasciata, Pseudocaranx dentex, Carangidae, Mediterranean Sea, Uncommon species, FADs, Fisheries

\section{INTRODUCTION}

Fishes of the family Carangidae, with 146 recognized species (FROESE \& PAULY, 2017), are mainly marine fishes (rarely in brackish waters) of tropical and subtropical waters of all oceans, although some occur in temperate waters. They are gonochoristic with external fertilization. During growth, they undergo changes so considerable that have likely been responsible for misidentification of species in some cases (BÖHLKE \& CHAPLIN, 1993). They are generally fast-swimming carnivorous, feeding mainly on small fishes, crustaceans and cephalopods. Some species are planktivorous. In Italian seas, and in general in the Mediterranean Sea, Pseudocaranx dentex (Bloch \& Schneider, 1801) is an uncommon carangid species. This fish, commonly known as white trevally, is an anfiatlantic coastal species, also recorded in the Mediterranean Sea and in the Indian Ocean (South Africa); while, records from Indo-west Pacific need confirmation (SMITH-VANIZ \& JELKS, 2006; SMITH-VANIZ et al., 2015). However, recently the species was recorded from Korea (KIM \& SONG, 2014). Juveniles, in particular, usually inhabit estuaries and shallow waters. Adults school and are often associated with rocky bottoms on the continental shelf. Only few records of $P$. dentex are known from the Italian seas (COSTA, 1991) 
and nearby areas (DULČíC \& PALLAORO, 2003). In the south-east coast of Sicily, the species was recorded for the first time in 2008 (TIRALONGO, 2008). Seriola fasciata (Bloch, 1793), commonly known as lesser amberjack, is an Atlantic immigrant of subtropical waters, recorded for the first time in the Mediterranean Sea in 1989, in the Balearic Islands (MASSUTÍ \& STEFANESCU, 1993). Subsequently, other records were reported from both the western and the eastern Basin: in Spain, France, Italy, Tunisia, Greece, Turkey, Lebanon, Syria, Israel and Malta (RIERA et al., 1995; COSTA, 1999; QUIGNARD \& TOMASINI, 2000; BRADAI et al., 2004; SAAD, 2005; CORSINI et al., 2006; SONIN et al., 2009; DEIDUN et al., 2011; BILECENOGLU et al., 2012; CROCETTA \& BARICHE, 2015). However, in Sicily, this species, which should be considered as a recent colonist, has become, especially in the last years, relatively common. COSTA (1999) reported the first records for Sicily (first in Italian sea) in 1993, from the northeast coast of Sicily (Tyrrhenian and Ionian Sea). Other records from Sicily come from the southern Tyrrhenian Sea and the Sicilian channel (ANDALORO \& POTOSCHI, 1997). Specimens were associated to floating objects. Indeed, S. fasciata is quite commonly caught around FADs (Fishing Aggregating Devices) with purse seine, used for the fishing of Coryphaena hippurus and Naucrates ductor (ANDALORO et al., 2005). CAVALLARO \& NAVARRA (2011) and CASTRIOTA \& SPINELLI (2016) have recently recorded the species from the Strait of Messina. In the first case, five specimens were caught with landing net near floating docks outside a small tourist port. Instead, in the second case, a single specimen was observed under a floating object in the canal of the Lake Faro. In most of the cases, records were of juveniles. Indeed, they are epipelagic and are usually found under floating objects, in coastal waters or offshore.

\section{MATERIAL AND METHODS}

In the south-east coast of Sicily (Fig. 1), from Siracusa to Portopalo of Capo Passero, between the years 2013-2017, we have recorded several specimens of $S$. fasciata and $P$. dentex. All the

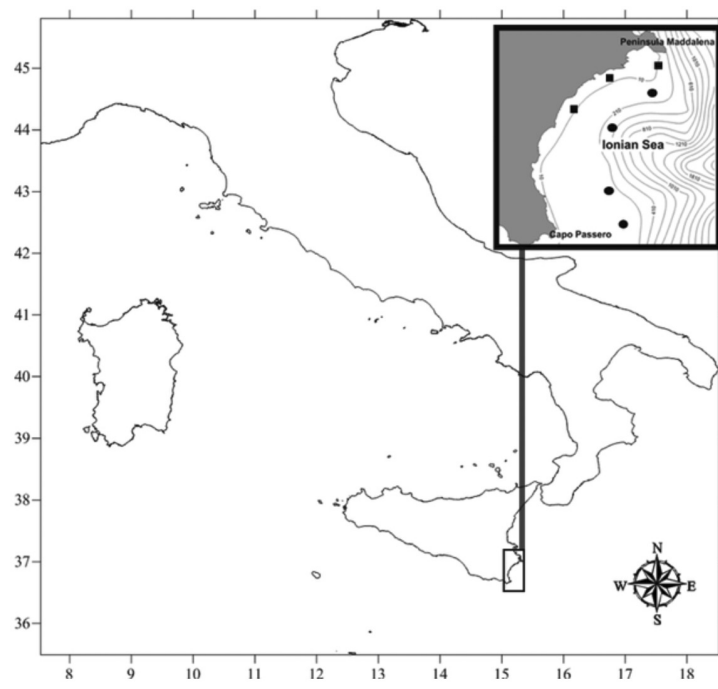

Fig. 1. Records of Pseudocaranx dentex (black squares) and Seriola fasciata (black circles indicate the area where the species was caught around FADs) in the south-east coast of Sicily (Ionian Sea)

observations were recorded through direct observation at landing points or through e-mail or Facebook Messenger from fishermen involved in the project "AlienFish" (https://www.entefaunamarinamediterranea.it/progetti-di-ricerca) of Ente Fauna Marina Mediterranea concerning alien and rare species in the Mediterranean Sea (TIRALONGO et al., 2018). The collected information included date of capture, location, number of specimens and fishing gear. All specimens of S. fasciata were caught with purse-seine around FADs, between half of August and December (during the fishing season of C. hippurus and N. ductor) 2015-2017. A single specimen was caught in each haul, with the exception of two hauls in 2017, in which were caught two specimens. The total length (TL) of 8 specimens was measured to the nearest $1 \mathrm{~cm}$. The specimens of $P$. dentex were caught with gillnet and trammel net, between February and June 2013-2015. All specimens were measured in total length (TL) to the nearest $1 \mathrm{~cm}$. The measurements were taken with a meter stick.

\section{RESULTS}

A total of 31 juvenile specimens of S. fasciata were caught in the period 2015-2017 in the 
whole study area. These represent the first welldocumented records of $S$. fasciata in the southeast coast of Sicily (Ionian Sea). The total length (TL) of the measured specimens ranged from 15 to $28 \mathrm{~cm}$. Juveniles showed 7 irregular dark bars on body. Another small dark spot was present on the caudal peduncle and an irregular dark bar extended from the posterior edge of the eye to the anterior dorsal surface, between the head and the first dorsal fin (COSTA, 1999). The specimen in the picture (Fig. 2) was caught off the coast of Marzamemi $\left(36.74875^{\circ} \mathrm{N}, 15.13649^{\circ} \mathrm{E}\right)$ on 20 November 2015.

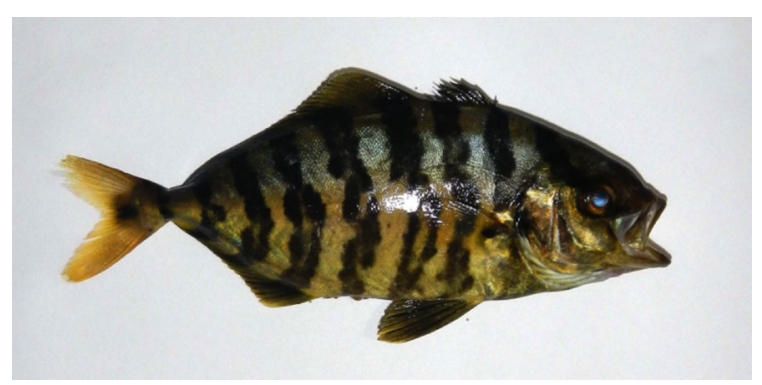

\begin{tabular}{|c|c|c|c|}
\hline Species & $\begin{array}{l}\text { Dates of } \\
\text { capture }\end{array}$ & $\begin{array}{c}\text { Fishing } \\
\text { gear }\end{array}$ & $\begin{array}{c}\mathrm{N}^{\circ} \text { of } \\
\text { specimens }\end{array}$ \\
\hline \multirow{3}{*}{$\begin{array}{c}\text { Seriola } \\
\text { fasciata }\end{array}$} & $\begin{array}{l}\text { August- } \\
\text { December } \\
2015\end{array}$ & $\begin{array}{l}\text { purse } \\
\text { seine }\end{array}$ & 11 \\
\hline & $\begin{array}{l}\text { August- } \\
\text { December } \\
2016\end{array}$ & $\begin{array}{l}\text { purse } \\
\text { seine }\end{array}$ & 7 \\
\hline & $\begin{array}{l}\text { August- } \\
\text { December } \\
2017\end{array}$ & $\begin{array}{l}\text { purse } \\
\text { seine }\end{array}$ & 13 \\
\hline \multirow{3}{*}{$\begin{array}{c}\text { Pseudocaranx } \\
\text { dentex }\end{array}$} & $\begin{array}{c}\text { 23th March } \\
2013\end{array}$ & $\begin{array}{l}\text { gill } \\
\text { net }\end{array}$ & 1 \\
\hline & $\begin{array}{l}\text { 20th June } \\
2014\end{array}$ & $\begin{array}{c}\text { trammel } \\
\text { net }\end{array}$ & 1 \\
\hline & $\begin{array}{c}16 \text { th } \\
\text { February } \\
2015\end{array}$ & $\begin{array}{c}\text { trammel } \\
\text { net }\end{array}$ & 1 \\
\hline
\end{tabular}

Table 1. Dates of capture, fishing gear and number of specimens caught of Seriola fasciata and Pseudocaranx dentex in the south-east coast of Sicily (Ionian Sea)

Fig. 2. Juvenile specimen of Seriola fasciata caught in Marzamemi with purse seine around FADs

It was $17 \mathrm{~cm}$ in total length. Between the years 2013-2015, we have instead recorded only 3 specimens of $P$. dentex, between Siracusa and Avola. In this species, the body is relatively elongated and laterally compressed, bearing scutes on the posterior part of the lateral line. In live and fresh specimens, along the body, it is often visible a yellow midlateral stripe, thicker in the posterior part. On the upper part of the posterior margin of the opercle, there is a black spot (COSTA, 1991). They ranged between 30-40 $\mathrm{cm}$ in total length (TL). The specimen caught in Avola was $31 \mathrm{~cm}$ (Fig. 3) and was caught

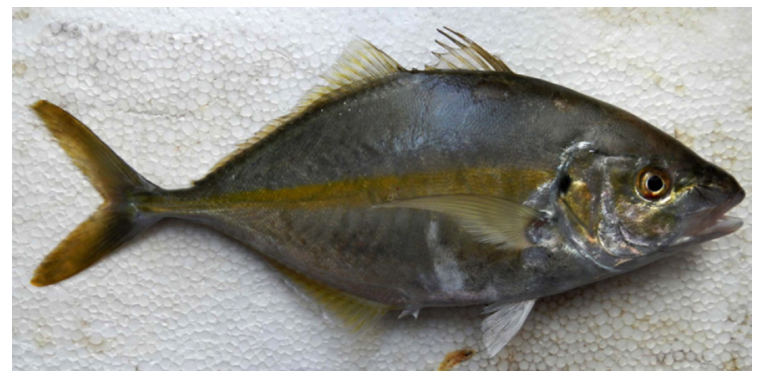

Fig. 3. Specimen of Pseudocaranx dentex caught in Avola with gill net with gillnet on 23th March 2013 at a depth of 6 $\mathrm{m}\left(36.88188^{\circ} \mathrm{N}, 15.14326^{\circ} \mathrm{E}\right)$. The other two specimens were caught in Siracusa $\left(16^{\text {th }}\right.$ February 2015) and Cassibile (20 $0^{\text {th }}$ June 2014) with trammel net, respectively at a depth of 12 and $9 \mathrm{~m}$. All details of the catches are summarized in Table 1.

\section{DISCUSSION}

On the basis of the over-mentioned studies and our study, we can consider $S$. fasciata as a relatively common species in all the east coast of Sicily, from Messina to Portopalo of Capo Passero, that is becoming ever more common and widespread in the central Mediterranean Sea. However, although juveniles of $S$. fascia$t a$ are relatively common in the area, around FADs in summer and autumn, their occurrence is not necessarily indicative of the presence of a well-established population. Indeed, juveniles of this species are epipelagic and their occurrence was strictly restricted to the presence of FADs; furthermore, eggs may be transferred by currents in the study area from other areas where the species is actually established. On the other 
hand, only the presence of mature adults in the area could substantiate that the species was established. However, due to the similarity between the adults of $S$. dumerili and $S$. fasciata, fishermen are generally not able to distinguish the adults of the species, that can be identified only by experts. Indeed, in adults (and larger juveniles) of $S$. fasciata the body show a more uniform color, without dark bars (which make juveniles of this species easily distinguishable from juveniles of $S$. dumerili). Adults are bentho-pelagic in shelf waters. Furthermore, we cannot exclude misidentification cases of $S$. fasciata as $S$. dumerili, so that the presence and abundance of S. fasciata in the Mediterranean Sea is probably underestimated. Indeed, the most of the records are of juveniles, which are more easily identifiable than adults. Instead, $P$. dentex must be considered uncommon, occasionally caught close to shore with trammel nets or gillnets.
Although $P$. dentex in Sicily appears to be sporadic, it seems more common than in other Italian seas. Only further studies and monitoring programs, together with collaboration between fishermen, citizens and scientists, can contribute to a better understanding of the presence and abundance of these two carangid species in the Mediterranean Sea.

\section{ACKNOWLEDGEMENTS}

We are grateful to all the fishermen who participate to the project "AlienFish" of Ente Fauna Marina Mediterranea for their kind collaboration, in particular to Fabio MARINO, Salvo MARINO, Paolo CAMPISI, Daniele CAMPISI, Paolo Silvia and Mirko QUADARELLA. Many thanks to the two anonymous reviewers whose comments improved the manuscript.

\section{REFERENCES}

ANDALORO, F., M. FALAUTANO, M. SINOPOLI, F.M. PASSARELLI, C. PIPITONE, P. ADDIS, A. CAU \& L. CASTRIOTA. 2005. The lesser amberjack Seriola fasciata (Perciformes: Carangidae) in the Mediterranean: a recent colonist? Cybium, 29: 141-145.

ANDALORO, F. \& A. POTOSCHI. 1997. Ichthyofauna associated to fish aggregation devices in the southern Tyrrhenian Sea. Proceedings of the Workshop on the biology and fishery of dolphin-fish and related species. Palma de Mallorca, pp 475.

BILECENOGLU, M., M. KAYA, B. CIHANGIR \& E. ÇIÇEK. 2012. An updated checklist of the marine fishes of Turkey. Turkish Journal of Zoology, 38: 901-929.

BÖHLKE, J.E. \& C.C.G. CHAPLIN. 1993. Fishes of the Bahamas and adjacent tropical waters. Univ. of Texas Press, Austin, USA, pp. 731.

BRADAI, M.N., J.-P. QUIGNARD, A. BOUAIN, O. JARBOUI, A. OUANNES-GHORBEL, L. BEN ABDALLAH, J. ZAOUALI \& S. BEN SALEM. 2004. Ichtyofaune autochtone et exotique des côtes tunisiennes: recensement et biogéographie. Cybium, 28(4): 315-328.
CASTRIOTA, L. \& A. SPINELLI. 2016. First record of Seriola fasciata (Carangidae) in the SCI of Capo Peloro - Laghi di Ganzirri, Sicily. In: New Mediterranean Marine Biodiversity Records. Mediterranean Marine Science, 17(1): 230-252.

CAVALlARO, M. \& E. NAVARRA. 2011. The first record of Seriola fasciata (Bloch, 1793) (Osteichthyes: Carangidae) in the Strait of Messina and its maintenance in conditions of captivity. Natura Rerum, 1: 51-54.

CORSINI, M., P. MARGIES, G. KONDILATOS \& P.S. ECONOMIDIS. 2006. Three new exotic fish records from the SE Aegean Greek waters. Scientia Marina, 70(2): 319-323.

COSTA, F. 1991. Atlante dei pesci dei mari italiani. Mursia, Milano, pp. 438.

COSTA, F. 1999. I pesci del Mediterraneo: stadi larvali e giovanili. Grafo Editor, Messin, p. 285.

DEIDUN, A., L. CASTRIOTA \& S. ARRIGO. 2011. A tale of two Atlantic fish migrants: records of the lesser amberjack Seriola fasciata and the African hind Cephalopholis taeniops from the Maltese Islands. Journal of the Black Sea/ 
Mediterranean Environment, 17(3): 223-233 CROCETTA, F. \& M. BARICHE. 2015. Six new records from Lebanon, with general implications for Mediterranean alien fauna. In: New Mediterranean Biodiversity Records. Mediterranean Marine Science, 16(3): 682-702.

DULČIĆ, J. \& A. PALLAORO. 2003. New additional records of imperial blackfish, Schedophilus ovalis (Cuvier, 1833), white trevally, Pseudocaranx dentex (Bloch \$ Schneider, 1801), and Atlantic pomfret, Brama brama (Bonnaterre, 1788), in the eastern Adriatic. ANNALES, Series Historia Naturalis, 13: 149-154. FROESE, R. \& D. PAULY. 2017. FishBase. World Wide Web electronic publication. www.fishbase.org, version (02/2017).

KIM, M.J. \& C.B. SONG. 2014. New record of the White Trevally, Pseudocaranx dentex (Carangidae, Perciformes) from Korea. Korean Journal of Ichthyology, 26(4): 340-344.

MASSUTÍ, E. \& C. STEFANESCU. 1993. First record of Seriola fasciata (Bloch, 1793) (Osteichthyes: Carangidae) in the Mediterranean. Journal of Fish Biology, 42(1): 143-144.

QUIGNARD, J.P. \& J.A. TOMASINI. 2000. Mediterranean fish biodiversity. Biologia Marina Mediterranea, 7(3): 1-66.

RIERA, F., A.M. GRAU, E. PASTOR \& S. POU. 1995. Faunistical and demographical observations in Balearic ichthyofauna. Meridionalization or subtropicalization phenomena. In: La
Méditerranée, variabilités climatiques, environnement et biodiversité, Actes du colloque Scientifique (Okeanos), Montpellier, France, pp. 213-220.

SAAD, A. 2005. Check-list of bony fish collected from the coast of Syria. Turkish Journal of Fisheries and Aquatic Science, 5: 99-106.

SMITH-VANIZ, W.F. \& H.L. JELKS. 2006. Australian trevallies of the genus Pseudocaranx (Teleostei: Carangidae), with description of a new species from Western Australia. Memoirs of the Museum of Victoria, 63: 97-106.

SMITH-VANIZ, W.F., J.T. WILLIAMS, F. PINA ARMAGOS, M. CURTIS \& J. BROWN. 2015. Pseudocaranx dentex. The IUCN Red List of Threatened Species 2015: e.T190070A16643997.

SONIN, O., SALAMEH P. \& D. GOLANI. 2009. First record of the lesser amberjack, Seriola fasciata (Actinopterygii: Perciformes: Carangidae), in the Levant. Acta Ichthyologica et Piscatoria, 39(1): 71-73.

TIRALONGO, F. 2008. L'Area Marina Protetta del "Plemmirio" (SR) - le attuali attività di pesca esercitate: la rete "sgammerrara". Bachelor's degree Thesis in Marine Biology and Ecology, University of Messina, $45 \mathrm{pp}$.

TIRALONGO, F., G. MESSINA, S. COCO \& B.M. LOMBARDO. 2018. On the presence of a well-established population of Lobotes surinamensis (Bloch, 1790) in the central Mediterranean Sea. ANNALES, Series Historia Naturalis, 28(1): 31-36. 


\title{
Novi zapisi dviju bitnica s jugoistočne obale Sicilije (Jonsko more) i razmatranja o njihovoj prisutnosti i obilju
}

\author{
Francesco TIRALONGO *, Daniele TIBULLO, Giuseppina MESSINA i \\ Bianca Maria LOMBARDO
}

*Kontakt e-pošta: fra.tiralongo@hotmail.it

\begin{abstract}
SAŽETAK
U ovom radu se iznosi novi nalaz šnjurka Pseudocaranx dentex (Bloch \& Schneider, 1801) i Seriola fasciata (Bloch, 1793) u Sredozemnom moru. Tijekom razdoblja 2013.-2017. autori su za obje vrste prikupili nekoliko zapisa o nalazu s jugoistočne obale Sicilije (Jonsko more). Na temelju autorskih i drugih objavljenih podataka, $S$. fasciata može se smatrati relativno čestom vrstom na tom području, obično uhvaćenom mrežom plivaricom oko FAD-ova u ljeto i jesen; dok je $P$. dentex rijetka vrsta povremeno ulovljena trostrukim ili jednostrukim mrežama stajaćicama. U ovom se radu iznose dokumentirani nalazi obje bitnice na jugoistočnoj obali Sicilije.
\end{abstract}

Ključne riječi: Seriola fasciata, Pseudocaranx dentex, Carangidae, Sredozemno more, rijetke vrste, FAD, ribarstvo 